NOTE

\title{
Use of larval supply in benthic ecology: testing correlations between larval supply and larval settlement
}

\author{
Gilles Miron*, Bernard Boudreau, Edwin Bourget \\ GIROQ, Département de Biologie, Université Laval, Ste-Foy, Québec, Canada G1K 7P4
}

\begin{abstract}
Conceptual models in marine benthic ecology have been reinforced with the use of larval recruitment as a key factor to predict fluctuations in the abundance and distribution of sessile adult populations. In turn, larval recruitment is determined using various indicators of planktonic larval abundance (larval supply). Based on plankton and settlement data collected over an entire settlement period of the barnacle Semibalanus balanoides, we explore the variability in the strength of the relationships between the abundance of newly settled individuals sampled daily at 3 shore levels and the daily larval abundance at 3 different depths over a $10 \mathrm{~d}$ study period. The best correlation was obtained between the number of larvae collected near the bottom and the number of spat sampled in the low intertidal. More than $75 \%$ of the variability in the abundance of newly settled spat in the lower intertidal was explained by variations in the larval abundance near the bottom. Larval abundance integrated over the entire water column explained $\sim 50 \%$ of the variability in low shore settlement, but failed to be significant. All other comparisons showed a lack of correlations. Our approach demonstrates that indicators of larval supply must be carefully and solidly documented to reflect the relationships between abundance of competent larvae, settlement intensity, and subsequently recruitment.
\end{abstract}

KEY WORDS: Larval supply $\cdot$ Larval settlement $\cdot$ Predictions Sampling · Barnacles Semibalanus balanoides

Studies carried out in areas with low or moderate settlement rates have indicated that the number of larvae that contact a substratum could be a determining factor in structuring benthic marine communities (Grosberg 1982, Underwood \& Denley 1984, Caffey 1985, Connell 1985, Gaines \& Roughgarden 1985, Gaines et al. 1985, Keough 1988, Underwood \& Fairweather 1989, Sutherland 1990, Minchinton \& Scheibling 1991). Recognized as a key variable, larval supply has thus been introduced in theoretical and experi-

•E-mail: C005@music.ulaval.ca mental ecology over the last decade (Lewin 1986 Menge \& Sutherland 1987, Roughgarden et al. 1987 , 1988, Young 1987, 1990, Underwood \& Fairweather 1989, Grosberg \& Levitan 1992). This has led to an increased focus on the abundance of early life history stages of marine benthic organisms, particularly within plankton (Hurlbut 1991, 1992, Minchinton \& Scheibling 1991, Bertness et al. 1992).

Several reviews (Underwood \& Denley 1984, Underwood \& Fairweather 1989) and experimental studies (Gaines \& Bertness 1993, Minchinton \& Scheibling 1993) have, however, stressed the importance of a sampling procedure that must be carefully designed to validate predictions from models based on the supplyside approach. For instance, the vertical distribution of barnacle larvae in the water column, which is related to hydrodynamics and larval behaviour, should be carefully examined before choosing a particular sampling depth as an indicator of larval supply. Barnacle larvae, in marine and estuarine environments, may be neustonic (i.e. near the surface) (Grosberg 1982, Le Fèvre \& Bourget 1991, 1992), suprabenthic (i.e. near the sea floor) (Bousfield 1955, Grosberg 1982), or uniformly distributed in the water column (de Wolf 1973). Theoretically, in non-oscillating systems (no tide), predicted abundances and vertical zonations of newly settled spat should be highly correlated to the depth distribution of larvae in the plankton. In contrast, in an oscillating system, newly settled spat could exhibit 3 different patterns depending on the vertical distribution of the larvae and duration of immersion at a particular shore level. (1) When competent larvae are neustonic, settlement should occur following the shape of the tidal oscillation. In the present study, the shape of the tidal oscillation in SW New Brunswick follows an harmonic curve over the intertidal zone with a maximum near mean tide level (Thomas et al. 1983). 
(2) When cyprids are distributed homogeneously in the water column, settlement is expected to increase monotonically from higher to lower shore levels in proportion to the duration of immersion at each level. Finally, (3) when the distribution of cyprids is skewed towards the seabed, then only the lower levels of the shore should be colonized. In the latter case, the slope of the curve relating settlement to elevation on shore should always be steeper than for the case when cyprids are distributed homogeneously.

The above illustrates the necessity of adapting sampling design to larval behaviour (e.g. vertical distribution) to obtain adequate estimates of larval supply. Variables such as the number of competent larvae per unit volume at a given depth may lead to erroneous estimates of recruitment, particularly in tidal systems, if used to predict settler abundances at all elevations. Conversely, integrating the data over time or space (throughout the water column) may decrease the predictor's sensitivity. Ignoring these limitations impedes the development of adequate predictive models. The present study explores the variability in the strength of the relationships between the daily abundance of newly settled individuals and the daily larval abundance in a sessile species. The barnacle Semibalanus balanoides was used as a model species to evaluate the validity of different indicators of larval supply.

Materials and methods. Larvae and newly settled spat of the barnacle Semibalanus balanoides were sampled every day during the settlement period between 14 and 24 May 1993 (except 19 May) in St. Andrews, New Brunswick (Canada). The study site at St. Andrews (Passamaquoddy Bay) is characterized by a mean tidal amplitude of $5.6 \mathrm{~m}$ and a mean water level of $4.1 \mathrm{~m}$ above lowest water of spring tide [see Thomas et al. (1983) and Chabot \& Bourget (1988) for details concerning the study area]. Larval distribution was determined daily from plankton samples collected by filtering $2000 \mathrm{l}$ of water through $64 \mathrm{\mu m}$ plankton netting using a centrifugal pump (Monark BSGF-8) at 5 different depths (surface, 0.5, 1.0, 1.5, and $4.0 \mathrm{~m}$ ). At each depth, a water sample (no replication) was pumped for $5 \mathrm{~min}$ at a calibrated flow rate of $\sim 400 \mathrm{l}$ min $^{-1}$ during daylight. Samples were taken at 1 location (near the pier) at high tide during slack water periods and fixed in $4 \%$ buffered formalin immediately upon collection. Water depth at the sampling location was $4.6 \mathrm{~m}$. Newly settled spat distribution was determined daily at low tide water level from $3.66 \times$ $0.15 \times 0.03 \mathrm{~m}$ planks installed vertically on the pillars of the pier at the beginning of the settlement period ( 3 replicates). The upper third of the plank $\left(0.18 \mathrm{~m}^{2}\right)$ was considered to be the high intertidal, the mid third the mid intertidal, and the lower third the low intertidal level. The center of each plank section corresponded to $4.11,2.90$, and $1.68 \mathrm{~m}$ levels above lowest water of spring tide, respectively. The planks were totally immersed at high tide and totally emersed at low tide. Newly settled individuals ( $<24 \mathrm{~h}$ old) at each tidal level were counted daily on the planks and removed with a scalpel.

Linear correlations (r) were used to examine the relationships between daily planktonic cyprid abundances (PCA) for different sampling depths in the water column (neustonic, data from surface, 0.5, and $1.0 \mathrm{~m}$ depths pooled; intermediate $1.5 \mathrm{~m}$; suprabenthic $4.0 \mathrm{~m}$; and integrated over the entire water column) and daily abundances of newly settled spat (NSS) at different intertidal levels (high, mid, and low) over a $10 \mathrm{~d}$ period ( $\mathrm{n}=10$ ). Larvae from the first 3 sampling depths were pooled so that data corresponded to settlement data collected from the same level on the planks. Intermediate and suprabenthic water depths corresponded to mid and low intertidal levels on the planks, respectively. Since analysis involved the same PCA within each group of correlations, Bonferoni correction was applied on the probability level $\left[\alpha_{0.05,0.01,0.001}\right.$ divided by the number of comparisons ( $\mathrm{n}=3$ ); ${ }^{\mathrm{p}} \mathrm{p} \leq 0.017 ; \cdots \mathrm{p} \leq 0.003 ; \cdots \mathrm{p} \leq 0.0003$ ].

Results. Planktonic cyprids of Semibalanus balanoides had a predominantly suprabenthic distribution in the water column (Fig. 1A). Averaged over the sampling period, the daily relative abundance of cyprids showed that $-60 \%$ of individuals were col-
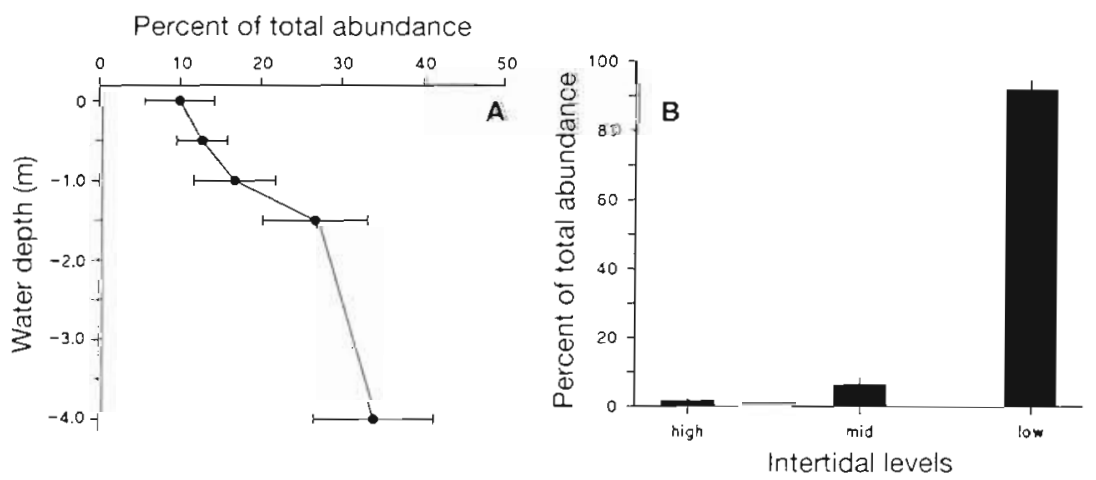

Fig. 1 Semibalanus balanoides. (A) Vertical distribution of larvae $(\%$ of total abundance) observed over a $10 \mathrm{~d}$ period (each day measured separately) at St. Andrews during the 1993 settlement period. Results are presented as means \pm SE of measurements $(n=10)$. (B) Newly settled spat distribution (\% of total abundance) observed over a $10 \mathrm{~d}$ period (each day measured separately). Results are presented as means \pm SE of measurements $(n=30$ : 3 replicates $\times 10 \mathrm{~d}$ ) 
Fig. 2. Semibalanus balanoides. Density of planktonic cyprids from $2000 \mathrm{l}$ samples at 3 water depths [(A) data from surface, $0.5 \mathrm{~m}$, and $1.0 \mathrm{~m}$ depths are pooled; (B) $1.5 \mathrm{~m} ;$ (C) $4.0 \mathrm{~m}$ ) and mean ( \pm SE) settlement at 3 intertidal levels [(A) high; (B) mid; (C) low intertidal levels] during the sampling period. Settled individuals were removed on each sampling date
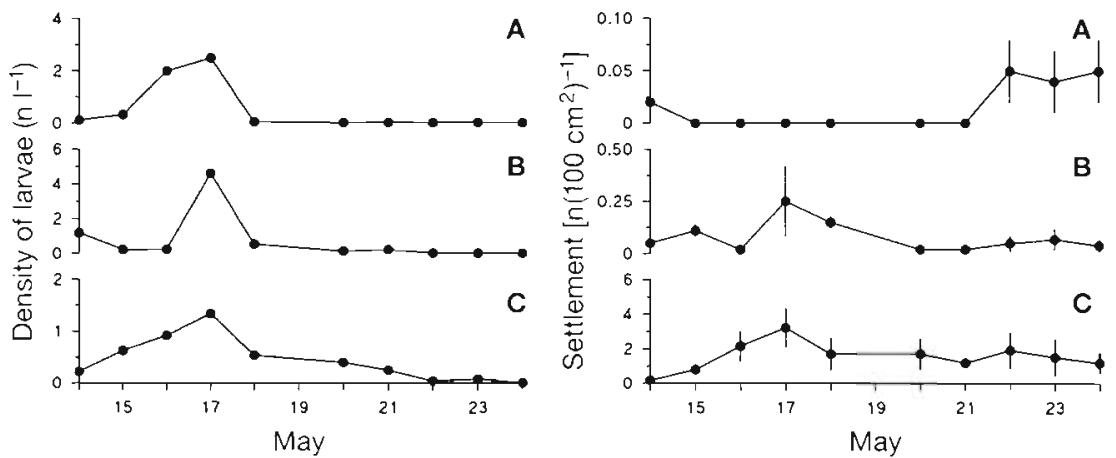

lected at depth $\geq 1.5 \mathrm{~m}$. In the same period, densities of newly settled individuals decreased with increasing intertidal level (Fig. 1B). Over $90 \%$ of newly settled spat were collected daily at low intertidal levels. Peaks of cyprid density in the water column were observed on 17 May at all depths (Fig. 2) and accounted for more than $50 \%$ of the total cypris larvae collected for each depth. Important settlement peaks were observed on 17 May at mid and low intertidal levels (Fig. 2). No peak occurred on that day at high intertidal level. Minor peaks were also detectable at the end of the sampling period $(22,23$, and 24 May) at all intertidal levels.

In order to evaluate the validity of different indicators of larval supply, the daily abundance of newly settled individuals sampled daily was correlated with the daily larval abundance over the $10 \mathrm{~d}$ study period. Table 1 summarizes correlations between the number of planktonic cyprids sampled at 3 different depths and the number of newly settled spat at 3 shore levels. The best correlation was obtained between the number of larvae near the bottom and the number of spat settled in the low intertidal $(r=0.87 ; p=0.003 ; n=10)$. About $75 \%$ of the variability in the abundance of newly settled spat in the lower intertidal was explained by variations in the larval abundance near the bottom. Integrated larval abundance also explained $-50 \%$ of the variability in low shore settlement. However, the correlation ( $p=0.019$ ) failed to be significant at the 0.017 significance level (Bonferoni correction). All other comparisons showed a lack of correlations.

Discussion. In this study, correlations between the abundance of larvae and the abundance of newly settled spat of Semibalanus balanoides, whose cypris larvae are suprabenthic, are much improved when low intertidal abundances of spat are related to nearbottom abundances of planktonic cyprids. Integrated larval abundance, though not significant at the 0.017 level (critical value after applying the Bonferoni correction), also describes low shore settlement reasonably well. Underwood (1972), working with intertidal prosobranchs, argued that the low zone on the shore will experience an integration of all water depths over a full tidal cycle, which in turn, should increase low shore settlement. Still, correlations were much stronger between near-bottom larval abundances and low shore settlement. Compared to the integrated larval abundance, the correlation between near-bottom larval abundance and low shore settlement showed a 50\% increase in the explained variability. This gain is important when one is considering field data. Integrating data over the entire water column is not a predictor as precise as anticipated. On the whole, these correlations show that there are limitations in trying to predict abundances of newly settled spat from larval supply. Minchinton \& Scheibling (1991) presented similar correlations between larval availability and settlement rate for the same species in Sandy Cove (Nova Scotia, Canada) in 1988 but did not emphasize this point.

Table 1. Semibalanus balanoides. Summary of results from linear correlations ( $r$ ) between daily planktonic cyprid abundances (PCA), for different sampling depths in the water column (neustonic: $0.0,0.5$, and $1.0 \mathrm{~m}$ depths; intermediate water: $1.5 \mathrm{~m}$; suprabenthic: $4.0 \mathrm{~m}$; and integrated over the water column without replication) and daily abundances of newly settled spat (NSS) at different intertidal levels (high. mid, and low) ( 3 replicates) over a $10 \mathrm{~d}$ period $(\mathrm{n}=10)$. Probability levels are $\left[\alpha_{0.05,0.01,0.001} / \text { no. of comparisons }(n=3)\right]_{i} \cdot p \leq$ $0.017 ; \cdots p \leq 0.003 ; \cdots p \leq 0.0003$ )

\begin{tabular}{|lllc|}
\hline \multicolumn{2}{l}{$\begin{array}{l}\text { Abundances compared } \\
\text { (PCA vs NSS) }\end{array}$} & $\mathrm{r}$ & $\mathrm{p}$ \\
\hline Neustonic & vs high & 0.30 & 0.404 \\
& vs mid & 0.01 & 0.909 \\
& vs low & 0.47 & 0.184 \\
Intermediate & vs high & 0.07 & 0.798 \\
& vs mid & 0.19 & 0.592 \\
& vs low & 0.04 & 0.863 \\
Suprabenthic vs high & 0.54 & 0.103 \\
& vs mid & 0.23 & 0.516 \\
Integrated & vs low & $0.87 \cdots$ & 0.003 \\
& vs high & 0.24 & 0.499 \\
& vs mid & 0.59 & 0.074 \\
& vs low & 0.72 & 0.019 \\
\hline
\end{tabular}



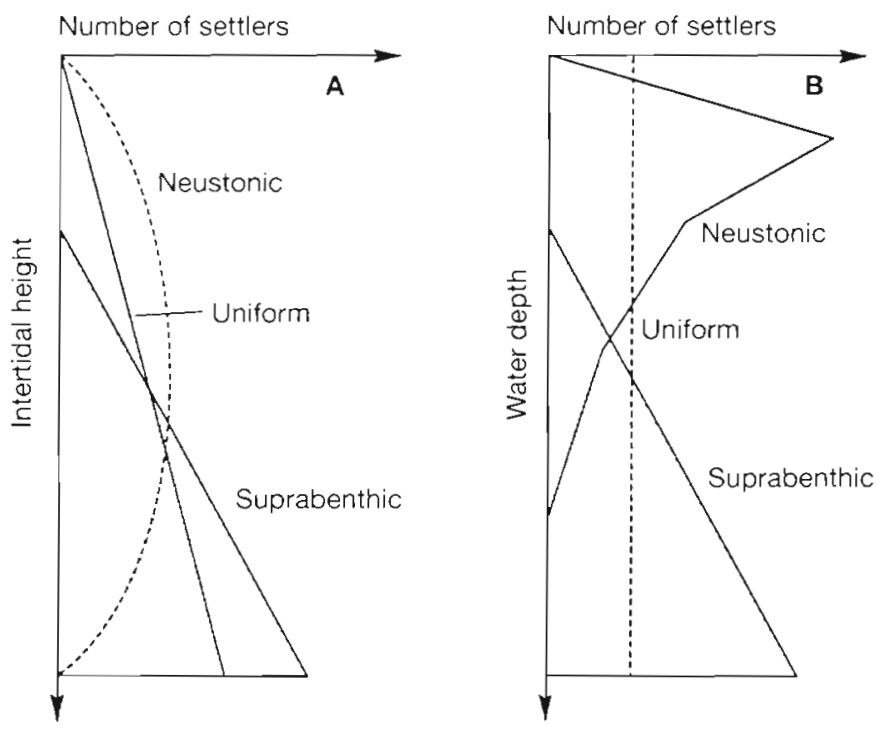

Fig. 3. Predicted relative abundances of newly settled spat on a substratum in (A) an oscillating system and (B) a non-oscillating system in relation to intertidal height or to water depth for barnacle species with neustonic, suprabenthic, and uniform cypris distributions in the water column assuming that settlement at a particular depth is solely proportional to the duration of the immersion period at that level [see Thomas et al. (1983) for the shape of the tidal oscillation in the study area]

Our results (Table 1), as well as those from Minchinton \& Scheibling (1991), validate a prediction illustrated in Fig. 3. When the distribution of cyprids is skewed towards the bottom (as in our study), the lower levels of the shore should be colonized at greater rates than high shore levels (Fig. 3A). We lack an experiment correlating the distribution of a species with neustonic larvae (or a species whose larvae are uniformly distributed in the water column) to the distribution of newly settled spat in the intertidal zone. Grosberg (1982) showed, however, that larvae of Balanus glandula had a neustonic distribution and that early settlers and adults were mostly distributed in the upper tidal zone. Similar results were also found by Hurlbut (1991) concerning the colonial ascidian Didemnum candidum.

The supply-side approach is interesting for predicting the structure and dynamics of marine benthic populations. However, we must bear in mind that underlying this approach is a complex mosaic of relationships between the planktonic larvae, newly settled spat, and the structure of the adult population. Special attention must be paid to the precise distribution of larvae in the water column to explain the abundances of newly settled spat and adults in the subtidal or intertidal zones before selecting indices of larval abundances and subsequently making predictions. Considering that most modelers generally use a reduced number of controlling factors, the structure of the population might, in fact, be indeterminate (i.e. variable and probably unpredictable in time and space), using larval supply only without considering important variability sources such as larval behaviour and hydrodynamics in the pelagic phase. Consequently, predictions from models may be confounded. Moreover, we suggest that the availability of competent larvae, habitat quality, and duration of the immersion period, in the case of populations inhabiting tidal systems, be measured to adequately predict the structure and dynamics of marine benthic populations. The aim of this comment is to send a note of caution to those attempting to shortcut adequate evaluation of distribution and abundance of competent larvae.

Acknowledgements. Funding for this research has been provided by NSERC and FCAR grants to E.B., Faculté des Sciences et de Génie de l'Université Laval and GIROQ post-doctoral fellowships to G.M., and a NSERC post-doctoral fellowship to B.B. We thank G. Daigle, M. Harvey, L. Lapointe, and M. Meekan for helpful comments on the manuscript. Three anonymous reviewers supplied numerous suggestions which improved the clarity of the manuscript. Contribution to the program of GIROQ (Groupe Interuniversitaire de Recherches Océagraphiques du Québec.

\section{LITERATURE CITED}

Bertness MD, Gaines SD, Stephens EG, Yund PO (1992) Components of recruitment in populations of the acorn barnacle Semibalanus balanoides (Linnaeus). J exp mar Biol Ecol 156:199-215

Bousfield EL (1955) Ecological control of the occurrence of barnacles in the Miramichi estuary. Bull natn Mus Can $137: 1-69$

Caffey HM (1985) Spatial and temporal variation in settlement and recruitment of intertidal barnacles. Ecol Monogr 55:313-332

Chabot R, Bourget $E$ (1988) Influence of substratum heterogeneity and settled barnacle density on the settlement of cypris larvae. Mar Biol 97:45-56

Connell JH (1985) The consequences of variation in inutial settlement vs. post-settlement mortality in rocky intertidal communities. J exp mar Biol Ecol 93:11-45

de Wolf P (1973) Distribution and dispersal of barnacle larvae. Neth J Sea Res 6:1-112

Gaines SD. Bertness M (1993) The dynamics of juvenile dispersal: why field ecologists must integrate. Ecology 74 : $2430-2435$

Gaines SA, Brown S, Roughgarden J (1985) Spatial variation in larval concentration as a cause of spatial variation in settlement for the barnacle. Balanus glandula. Oecologia $67: 267-272$

Gaines SD, Roughgarden J (1985) Larval settlement rate: a leading determinant of structure in an ecological community of the marine intertidal zone. Proc natl Acad Sci USA 82:3707-3711 
Grosberg RK (1982) Intertidal zonation of barnacles: the influence of planktonic zonation of larvae on vertical distribution of adults. Ecology 63:894-899

Grosberg RK, Levitan DR (1992) For adults only? Supply-side ecology and the history of larval biology. Trends Ecol Evol $7: 130-133$

Hurlbut CJ (1991) The effects of larval abundance, settlement and juvenile mortality on the depth distribution of a colonial ascidian. J exp mar Biol Ecol 150:183-202

Hurlbut CJ (1992) Larval release and supply predict temporal variation in settlement of a colonial ascidian. Mar Ecol Prog Ser 80:215-219

Keough MJ (1988) Benthic populations: is recruitment limiting or just popular? Proc 6th int Symp Coral Reef 1 $141-148$

Le Fèvre J, Bourget E (1991) Neustonic niche for cirripede larvae as a possible adaptation to long-range dispersal. Mar Ecol Prog Ser 74:185-194

Le Fèvre J, Bourget E (1992) Hydrodynamics and behaviour: transport processes in marine invertebrate larvae. Trends Ecol Evol 7:288-289

Lewin R (1986) Supply-side ecology. Science 234:25-27

Menge BA, Sutherland JP (1987) Community regulation: variation in disturbance, competition, and predation in relation to environmental stress and recruitment. Am Nat 130 $730-757$

Minchinton TE, Scheibling RE (1991) The influence of larval supply and settlement on the population structure of barnacles. Ecology 72:1867-1879

Minchinton TE, Scheibling RE (1993) Variations in sampling procedure and frequency affect estimates of recruitment

This note was submitted to the editor of barnacles. Mar Ecol Prog Ser 99:83-88

Roughgarden J, Gaines SD, Pacala SW (1987) Supply-side ecology: the role of physical transport processes. In: Gee JHR, Giller PS (eds) Organization of communities: past and present. Blackwell Scientific Press, London, p 491-518

Roughgarden J, Gaines S, Possingham H (1988) Recruitment dynamics in complex life cycles. Science 241:1460-1466

Sutherland JP (1990) Recruitment regulates demographic variation in a tropical intertidal barnacle. Ecology 71 955-972

Thomas MLH, Arnold DC, Taylor ARA (1983) Rocky intertidal communities. In: Thomas MLH (ed) Marine coastal systems of the Quoddy region, New Brunswick. Can Spec Publ Fish Aquat Sci 64:35-73

Underwood AJ (1972) Tide model analysis of the zonation of intertidal prosobranchs: I. Four species of Littorina (L.). $J$ exp mar Biol Ecol 9:239-255

Underwood AJ, Denley EJ (1984) Paradigms, explanations and generalizations in models for the structure of intertidal communities on rocky shores. In: Strong DR, Simberloff DS, Abele LG, Thistle AB (eds) Ecological communities: conceptual issues and the evidence. Princeton University Press, Princeton NJ, p 151-180

Underwood AJ, Fairweather PG (1989) Supply-side ecology and benthic marine assemblages. Trends Ecol Evol 4 $16-20$

Young CM (1987) Novelty of 'supply-side' ecology. Science 235:415-416

Young CM (1990) Larval ecology of marine invertebrates: a sesquicentennial history. Ophelia 32:1-48

Manuscript first received: August 17, 1994

Revised version accepted: March 8, 1995 